\section{Effects of Thidiazuron on Grapevine Axillary Buds Cultivated in Vitro}

\author{
Ivana Gribaudo \\ Centro di Studio per il Miglioramento Genetico della Vite, Consiglio \\ Nazionale delle Ricerche, Via P. Giuria 15, I-10126 Turin, Italy
}

\section{Anna Fronda \\ Istituto di Coltivazioni Arboree dell'Università Via P. Giuria 15, I-10126 Turin, Italy}

Additional index words. vitis vinifera, growth substances, micropropagation
$N$-phenyl- $N^{\prime}$-1,2,3-thiadiazol-5-ylurea [thidiazuron (TDZ)], a newly available phenylurea, has been reported to have high cytokinin activity at low concentrations. Its cytokinin-like effects on several species include promotion of growth in cell and callus cultures, stimulation of in vitro shoot proliferation and somatic embryogenesis, and budbreak of dormant trees (Matsuda and Hirabayashi, 1989; Mok et al., 1987). The aim of this work is to test grapevine response to TDZ during in vitro culture of axillary buds.

Woody cuttings of Vitis vinifera L. 'Barbera' (clone CVT-AT84) were forced to sprout. After 6 weeks, the new shoots were collected and sterilized by immersion in a $25 \%(\mathrm{v} / \mathrm{v})$ aqueous solution of a $7 \%$ chlorine detergent for $15 \mathrm{~min}$. Explants, isolated from the sterilized shoots, were nodal segments formed by the axillary buds plus a small part of the adjacent tissues of stem and petiole $(0.8 \mathrm{~cm}$ average length). Buds were cultured on an agarized Nitsch and Nitsch (1969) medium, modified by increasing thiamine $\mathrm{HCl}$ to $15 \mu \mathrm{M}$ and FeEDTA to $200 \mu \mathrm{M}$, and containing $10,1,0.1,0.01,0.001$, or $0 \mu \mathrm{M}$ TDZ (Schering S.p.A., Segrate, Italy). The $\mathrm{pH}$ of the media was adjusted to 5.6 before autoclaving. Cultures were grown at $23 \mathrm{C}$ with a 16-h photoperiod and $50 \mu \mathrm{mol} \cdot \mathrm{s}^{-1} \cdot \mathrm{m}^{-2}$

Received for publication 15 Feb. 1990. Contribution no. 215 of Centro Miglioramento Genetico Vite, CNR Torino. We thank Schering S.p.A., Divisione Arzricoltura (Segrate. MI. Italia) for donating the thidiazuron used in this study. The cost of publishing this paper was defrayed in part by the payment of page charges. Under postal regulations, this paper therefore must be hereby marked advertisement solely to indicate this fact. photosynthetic photon flux. The experiment was conducted twice, and the number of explants per treatment varied between 16 and 26 , depending on the incidence of contamination.

After 1 month of culture, shoots $(1 \mathrm{~cm}$ long) from unrooted nodal segments were excised and placed on a growth regulatorfree medium (Nitsch and Nitsch, 1969, modified as described above).

TDZ was effective in promoting bud outgrowth (Table 1) and increasing the number of shoots obtained from a single bud. It must be noted, however, that grapevine usually shows a relatively low proliferation rate even in the presence of benzyladenine (BA) in the medium. In previous experiments with 'Barbera' on the same basal medium with $5 \mu \mathrm{M}$ BA, about three shoot/nodal segments were obtained (unpublished results).

Some of the explants also produced roots from the basal part of the nodal segment, and at concentrations of TDZ above $0.1 \mu \mathrm{M}$, the incidence of rooting was reduced or eliminated (Table 1). Symptoms of vitrification and leaf malformations, such as deeply lobed leaf blades, dentations, and presence of anthocyanins, became more pronounced as concentration of TDZ increased, with $0.1 \mu \mathrm{M}$ or higher concentrations causing thickening of the stems. At the two highest doses, large amounts of callus were formed at the base of the explants. Shoot number and length decreased at the highest concentration.

After excision of shoots from the unrooted nodal segments and their transfer to a growth regulator-free medium, the first one to two newly formed leaves showed malformations when the shoots were grown previously on medium containing 1 or $10 \mu \mathrm{M}$ TDZ. Percentage of shoot rooting ranged from 50\% to $80 \%$, except for shoots from $10 \mu \mathrm{M}$ TDZ, which did not root. Some of the results presented here are similar to those reported for other species. On this clone of grape, low concentrations promote bud outgrowth and development of relatively healthy shoots, showing that TDZ could be used to multiply grapevine in vitro, but the negative effects of TDZ seem to be pronounced. Experiments on different grapevine cultivars are needed to confirm TDZ effectiveness

\section{Literature Cited}

Matsuda, N. and T. Hirabayashi. 1989. Embryogenic cell lines from somatic embryos of grape (Vitis vinifera L. ) Plant Cell Rpt. 7:684-687.

Mok, M.C.:D.W.S. Mok, J.E. Turner, and C.V. Mujer. 1987. Biological and biochemical effects of cytokinin-active phenylurea derivates in tissue culture systems. HortScience 22(61:11941197.

Nitsch, J.P. and C. Nitsch. 1969. Haploid plants from pollen grains. Science 163:85-87.
Table 1. Effects of TDZ on proliferation and rooting of grapevine nodal segments after 1 month of culture in vitro. Morphological visual evaluation rating: from 0 (strongly vitrified and/or malformed shoots) to 4 (fully normal and healthy shoots).

\begin{tabular}{|c|c|c|c|c|c|}
\hline $\begin{array}{c}\mathrm{TDZ} \\
\text { concn } \\
(\mu \mathrm{M})\end{array}$ & $\begin{array}{c}\text { Sprouted } \\
\text { explants } \\
(\%)\end{array}$ & $\begin{array}{c}\text { Rooted } \\
\text { explants } \\
(\%) \\
\end{array}$ & $\begin{array}{c}\text { No. shoots/ } \\
\text { explant }\end{array}$ & $\begin{array}{l}\text { Shoot } \\
\text { length } \\
\text { (mm) }\end{array}$ & $\begin{array}{c}\text { Morphological } \\
\text { evaluation } \\
(0-4)\end{array}$ \\
\hline 0 & 47 & 42 & 1.11 & 10.7 & 3.2 \\
\hline 0.001 & 81 & 57 & 1.00 & 11.2 & 2.4 \\
\hline 0.01 & 82 & 64 & 1.17 & 13.9 & 2.4 \\
\hline 0.1 & 75 & 12 & 1.59 & 13.3 & 1.9 \\
\hline 1 & 91 & 0 & 2.15 & 10.9 & 1.2 \\
\hline 10 & 96 & 0 & 1.72 & 9.5 & 0.5 \\
\hline \multicolumn{6}{|c|}{ Source of variance } \\
\hline Linear & * & * & * & $*$ & $* *$ \\
\hline Quadratic & NS & ** & ** & NS & $* *$ \\
\hline Lack of fit & NS & NS & NS & NS & NS \\
\hline
\end{tabular}

NS,*,**Nonsignificant or significant at $P=0.05$ or 0.01 , respectively. 